\title{
Free surface profile and inception point as characteristics of aerated flow over stepped spillway: Numerical study
}

\author{
Chakib BENTALHA ${ }^{\mathrm{ABCDEF} \bowtie}$, Mohammed HABI ${ }^{\mathrm{CDEF}}$
}

Abou Bakr Belkaid University, Department of Hydraulic, Faculty of Technology, Tlemcen, 13000, BP 230, Algeria; e-mail: c_bentalha@yahoo.fr,moha.habi@gmx.de

For citation: Bentalha C., Habi M. 2019. Free surface profile and inception point as characteristics of aerated flow over stepped spillway: Numerical study. Journal of Water and Land Development. No. 42 (VII-IX) p. 42-48. DOI: 10.2478/jwld-20190043 .

\begin{abstract}
Stepped spillway is hydraulic structure designed to dissipate the excess in kinetic energy at the downstream of dams and can reduce the size of stilling basin at the toe of the spillway or chute. The flow on a stepped spillway is characterised by the large aeration that can prevent or reduce the cavitation damage. The air entrainment starts where the boundary layer attains the free surface of flow; this point is called "point of inception". Within this work the inception point is determined by using software Ansys Fluent where the volume of fluid (VOF) model is used as a tool to track the free surface thereby the turbulence closure is derived in the $k-\varepsilon$ turbulence standard model. This research aims to find new formulas for describe the variation of water depth at step edge and the positions of the inception point, at the same time the contour map of velocity, turbulent kinetic energy and strain rate are presented. The found numerical results agree well with experimental results like the values of computed and measured water depth at the inception point and the numerical and experimental inception point locations. Also, the dimensionless water depth profile obtained by numerical method agrees well with that of measurement. This study confirmed that the Ansys Fluent is a robust software for simulating air entrainment and exploring more characteristics of flow over stepped spillways.
\end{abstract}

Key words: Ansys Fluent, free surface, inception point, standard $k-\varepsilon$ model, stepped spillway, VOF model

\section{INTRODUCTION}

The main role of spillway is spilled the surplus water to the dam downstream. Evacuating the surplus of water to stalling basin creates high levels of kinetic energy. This energy may be decreased by construction of steps on the spillway [CHANSON 2001a]. The energy dissipated with steps was two to three times as great as the energy dissipated with a smooth surface [RICE, KADAVY 1996] and can reduce the size of stilling basin at the toe of the dam [CHANSON 2001b; Christodoulou 1993; RAJARATNAM 1990]. The performance of the stepped spillway is the presence of air which can prevent or reduce the cavitation erosion damage. The skimming flow regime down stepped chute is characterised by highly turbulence and the water flows as a coherent stream.
In the skimming flow regime, air entrainment occurs when the turbulent boundary layer thickness coincides with the water depth [CHANSON 1997]. This location is called the inception point (e.g. Fig. 1). At the inception point upstream, the flow is smooth and glassy whereas at the downstream of the inception point the flow becomes uniform as the depth of the air-water mixture grows. This position is characterised by two parameters: $L_{i}$ and $d_{i}$ (e.g. Fig. 1). The first is the distance from the start of growth of the boundary layer to the point of inception and other is the depth at the point of inception. The inception point of aeration of stepped spillways is placed further upstream than on smooth spillways. On smooth spillway, the position of the inception point is a function of the discharge and the roughness of the spillway. WoOD et al. [1983] proposed an approach to estimate $L_{i}$ and $d_{i}$. On stepped spillway, the position of the inception point is function of the discharge, 
spillway roughness, step geometry and spillway geometry. CHANSON [2001a] developed a method to determine the flow properties at the start of air entrainment with slopes greater or equal than $22^{\circ}$. BOES and HAGER [2003] also derived a mathematical formula enabling the determination of the distance between the start of the turbulent boundary layer and the inception point.

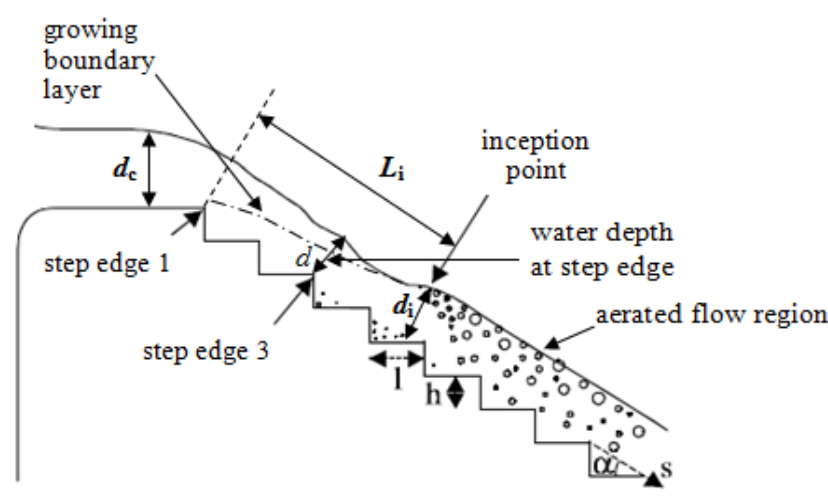

Fig. 1. Position of the inception point in stepped spillway; $d_{c}=$ critical flow depth, $L_{i}=$ longitudinal distance between inception point and crest, $d=$ water depth; source: own elaboration

The boundary layer thickness $(\delta)$ is important element in determining the positions of inception point of freesurface aeration and it is defined as the perpendicular distance from the pseudo-bottom to where the velocity is $99 \%$ of the free-stream velocity. ZHANG and CHANSON [2016] defined relationships to determine the evolution of boundary layer thickness with slopes equal $45^{\circ}$ :

$$
\frac{\delta}{L}=0.15\left(\frac{L}{k_{S}}\right)^{-0.37}
$$

Where: $\delta$ is the boundary layer thickness, $L$ is the streamwise distance from the start of the growth of the boundary layer, $k_{s}$ is the roughness height.

Most experimental research has been developed to characterise the flow over stepped spillway. Today, with the development of computational fluid dynamics (CFD) branch, flow over stepped spillway can be simulated to validate experimental results and to help in the design of stepped spillway together with the physical model. CHEN et al. [2002] simulated flow over a stepped spillway using $k-\varepsilon$ turbulence model. BomBARDELLi et al. [2011]. Simulated non-aerated region of the skimming flow in steep stepped spillways using 3D-FLOW. Numerical study of SARFARAZ et al. [2012] was performed to simulate and investigate flow characteristics over a steeply sloping stepped spillway. They used volume of fluid (VOF) to simulate interaction between air and water and turbulence was encountered by both Re-Normalisation Group (RNG) $k-\varepsilon$ and large eddy simulation (LES). EGHBALZADEH and JAVAN [2012] used Fluent commercial software for examining the performance of the VOF and mixture models in simulating skimming flow over stepped spillway. The computational results of mean velocity, span-wise vorticity, and growth of boundary layer thickness, obtained by QIAN et al. [2009] are compared with experimental data to choose the optimal turbulence model. CHENG et al. [2006] used a VOF model to investigate the normal velocity profiles responding to the steps as bed roughness. The RNG $k-\varepsilon$ model was chosen and their numerical results successfully reproduced the flow over the stepped spillway of the physical model.

In this study, skimming flow over stepped spillway was simulated by using Fluent software and VOF model was applied to define the free surface profile and to calculate volume fraction for each phase. This paper aims to develop new relationships for determining the variation of water level upstream of the inception point and the distance from the spillway crest to this point. Also to show the distribution of velocity, turbulent kinetic energy and shear strain rate along the stepped spillway. The found numerical results are compared with the existing experimental results [ZHANG, CHANSON 2015 2016].

\section{NUMERICAL MODEL}

Ansys Fluent computational fluid dynamics (2014) is used to solve the Reynolds-Averaged Navier-Stokes equations are based on momentum and mass conservation of multi-phase flow over stepped spillway. The standard $k-\varepsilon$ turbulence model is adopted to enclose the equations. This model is still a good tool for numerical simulation of flow in stepped spillways and verified by experimental and field data [CHEN et al. 2002].

\section{Continuity equation:}

$$
\frac{\partial \rho}{\partial t}+\frac{\partial \rho u_{i}}{\partial x_{i}}=0
$$

Momentum equation:

$$
\begin{gathered}
\frac{\partial \rho u_{i}}{\partial t}+\frac{\partial}{\partial x_{j}}\left(\rho u_{i} u_{j}\right)= \\
=-\frac{\partial p}{\partial x_{i}}+\rho g_{i}+\frac{\partial}{\partial x_{j}}\left\{\left(\mu+\mu_{t}\right)\left(\frac{\partial u_{i}}{\partial x_{j}}+\frac{\partial u_{j}}{\partial x_{i}}\right)\right\}
\end{gathered}
$$

Turbulence kinetic energy equation $-k$ :

$$
\frac{\partial}{\partial t}(\rho k)+\frac{\partial}{\partial x_{i}}\left(\rho k u_{i}\right)=\frac{\partial}{\partial x_{j}}\left[\left(\mu+\frac{\mu_{t}}{\sigma_{k}}\right) \frac{\partial k}{\partial x_{i}}\right]+G_{k}-\rho \varepsilon
$$

Turbulence dissipation rate energy equation $-\varepsilon$ :

$$
\begin{gathered}
\frac{\partial}{\partial t}(\rho \varepsilon)+\frac{\partial}{\partial x_{i}}\left(\rho \varepsilon u_{i}\right)= \\
=\frac{\partial}{\partial x_{j}}\left[\left(\mu+\frac{\mu_{t}}{\sigma_{\varepsilon}}\right) \frac{\partial \varepsilon}{\partial x_{i}}\right]+C_{\varepsilon 1} \frac{\varepsilon}{k} G_{k}-C_{\varepsilon 2} \rho \frac{\varepsilon^{2}}{k}
\end{gathered}
$$

Where: $\rho$ is density, $\mu$ is molecular viscosity, $p$ is pressure and $G_{k}$ is production of turbulent kinetic energy which can be given as:

$$
G_{k}=\mu_{t}\left(\frac{\partial u_{i}}{\partial x_{j}}+\frac{\partial u_{j}}{\partial x_{i}}\right) \frac{\partial u_{i}}{\partial x_{j}}=2 \mu_{t} S_{i j} \frac{\partial u_{i}}{\partial x_{j}}
$$

Where: $S_{i j}$ is shear strain rate and $\mu_{\mathrm{t}}$ is the turbulent viscosity that satisfies:

$$
\mu_{t}=\rho C_{\mu} \frac{k^{2}}{\varepsilon}
$$

$C_{\mu}=0.09$ is a constant determined experimentally; $\sigma_{k}$ and $\sigma_{\varepsilon}$ are turbulence Prandtl numbers for $k$ and $\varepsilon$ equation respectively, $\sigma_{k}=1.0, \sigma_{\varepsilon}=1.3, C_{\varepsilon 1}$ and $C_{\varepsilon 2}$ are $\varepsilon$ equation constants, $C_{\varepsilon 1}=1.44, C_{\varepsilon 2}=1.92$. 
These constants are defined by LAUNDER and SPALDING [1974].

The VOF method is applied to simulate the free surface between water and air (Ansys Fluent). In this approach, the tracking interface between air and water is accomplished by the solution of a continuity equation for the volume fraction of water:

$$
\frac{\partial \alpha_{w}}{\partial t}+\frac{\partial \alpha_{w} u_{i}}{\partial x_{i}}=0 ; 0 \leq \alpha_{w} \leq 1
$$

Where: $\alpha_{w}$ is volume fraction of water. In each cell, the sum of the volume fractions of air and water is unity. Volume fractions of air denote $\alpha_{a}$ can be given as:

$$
\alpha_{a}=1-\alpha_{w}
$$

The geometry of numerical model and boundary conditions are shown in Figure 2. The stepped spillway contains 12 identical steps, with $0.1 \mathrm{~m}$ height and $0.1 \mathrm{~m}$ length by step. The channel slope is $\theta=45^{\circ}$.

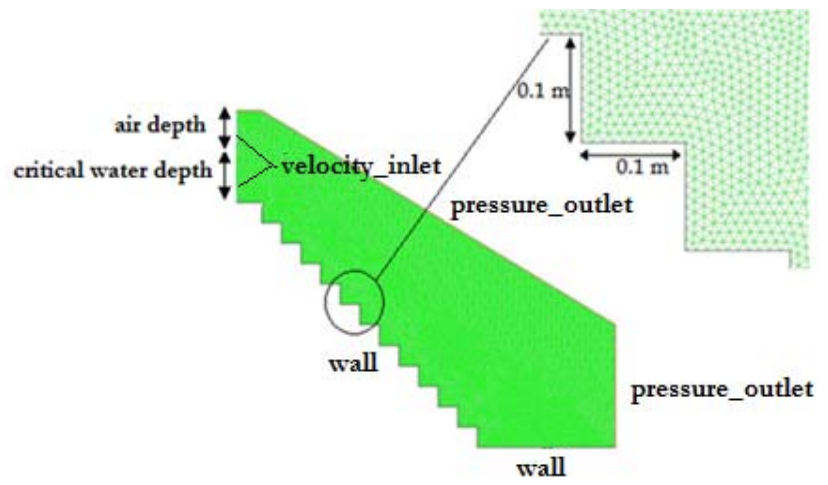

Fig. 2. Boundary conditions and numerical model of a stepped spillway; source: own elaboration

The two-dimensional numerical domain was divided into unstructured grids (triangular cell) that had a high adaptability to the complex geometry and boundary. Triangular meshes with $1 \mathrm{~cm}^{2}$ are used.

The boundary conditions in this study are velocity inlet as water inlet and air inlet, outlet as a pressure outlet type. The water depth at the inlet is critical flow depth. All of the walls as a stationary, no-slip wall. The viscosity layer near to the wall dealt with the standard wall function. Nondimensional distance $(y+)$ was adapted between 30 and 300 in wall zone with Ansys Fluent. The boundary conditions for the turbulent quantities such as $k$ and $\varepsilon$ can be calculated from Ansys Fluent:

$$
\begin{aligned}
& k=\frac{3}{2}\left(U_{\mathrm{avg}} I\right)^{2} \\
& \varepsilon=C_{u}^{3 / 4} \frac{k^{3 / 2}}{0.07 D_{H}}
\end{aligned}
$$

Where: $U_{\text {avg }}$ is the mean velocity of water flow inlet, $D_{H}$ is the hydraulic diameter and $I$ is turbulence intensity. To obtain the value of turbulence intensity, Ansys Fluent use the following formula derived from an empirical correlation for pipe flows:

$$
I=0.16\left(R e_{D H}\right)^{-1 / 8}
$$

\begin{tabular}{|c|c|c|c|}
\hline$d_{c}(\mathrm{~m})$ & $U_{\text {avg }}\left(\mathrm{m} \cdot \mathrm{s}^{-1}\right)$ & Wall roughness & Solution initialisation \\
\hline 0.09 & 0.944 & \multirow{3}{*}{$\begin{array}{l}\text { roughness height } \\
\quad=0.8 \mathrm{~mm}\end{array}$} & \multirow{6}{*}{$\begin{array}{l}\text { all variables of flow } \\
\text { was initialised from } \\
\text { water inlet zone }\end{array}$} \\
\hline 0.10 & 0.990 & & \\
\hline 0.11 & 1.036 & & \\
\hline 0.13 & 1.130 & \multirow{3}{*}{$\begin{array}{l}\text { roughness constant } \\
=0.5\end{array}$} & \\
\hline 0.15 & 1.210 & & \\
\hline 0.17 & 1.290 & & \\
\hline
\end{tabular}

The default value for turbulence intensity is 5\% (medium intensity) in Ansys Fluent. The numerical value of boundary conditions are listed in Table 1 .

Table 1. Inflow conditions

Explanations: $d_{c}=$ critical flow depth, $U_{\text {avg }}=$ mean velocity of water flow inlet.

Source: own elaboration.

\section{RESULTS AND DISCUSSION}

The results of the numerical simulation are compared with those obtained from the physical model. In this study, the position of the inception point are computed and compared with the experimental data by ZHANG and CHANSON [2015] for $0.7 \leq d_{c} / h \leq 1.7$, where $d_{c}$ is critical flow depth and $h$ is step height. In Ansys Fluent, air entrainment initiate when fraction of water $\alpha_{w}<1$ and with this method, the inception point is determined. Figure 3 presents a comparison the air entrainment simulated by VOF model and in experiments for different discharges. As can be seen from this figure, the calculated inception point is well agreed with that of measurement. At the inception point, the degree of turbulence was large enough to entrain air into the black water flow [CHENG et al. 2006], and then the volume fraction of water becomes less than unity [BENTALHA, HABI 2015]. This figure indicates also, that the inception point moves toward the basin floor when the discharge increases.

Table 2 summarises the characteristics of the inception point of free-surface aeration found by ZHANG and CHANSON [2016], and by using Ansys Fluent for different water discharge per unit width $(q)$.

Table 2. Measured and computed inception point

\begin{tabular}{|c|c|c|c|c|c|}
\hline \multicolumn{2}{|c|}{ Parameter } & \multicolumn{2}{c|}{$\begin{array}{c}\text { ZHANG and CHANSON } \\
{[2016]}\end{array}$} & \multicolumn{2}{c|}{ Ansys Fluent } \\
\hline$d_{c} / h$ & $\begin{array}{c}q \\
\left(\mathrm{~m}^{2} \cdot \mathrm{s}^{-1}\right)\end{array}$ & $L_{i}(\mathrm{~m})$ & $d_{i}(\mathrm{~m})$ & $L_{C F D}(\mathrm{~m})$ & $d_{C F D}(\mathrm{~m})$ \\
\hline 0.9 & 0.085 & 0.57 & 0.033 & 0.43 & 0.035 \\
\hline 1.0 & 0.099 & 0.57 & 0.041 & 0.56 & 0.043 \\
\hline 1.1 & 0.114 & 0.57 & - & 0.56 & 0.045 \\
\hline 1.3 & 0.147 & 0.85 & 0.049 & 0.78 & 0.052 \\
\hline 1.5 & 0.182 & 0.85 & 0.061 & 0.91 & 0.060 \\
\hline 1.7 & 0.219 & 1.13 & 0.062 & 1.16 & 0.061 \\
\hline
\end{tabular}

Explanations: $d_{c}=$ critical flow depth, $h=$ step height, $q=$ flow rate, $L_{i}$, $L_{C F D}=$ measured and computed longitudinal distance, $d_{i}, d_{C F D}=$ measured and calculated water depth at the inception point.

Source: own study.

Table 2 shows good agreement between the observed and numerical results. As can be seen from this table, the calculated water depth at the inception point $\left(d_{C F D}\right)$ are very close to the experimental values $\left(d_{i}\right)$. 
Although the difference between the numerical and experimental inception point locations $\left(L_{i}\right.$ and $\left.L_{C F D}\right)$ are small (see also Fig. 3), except at low discharge the difference is slightly higher. This difference may be due to the VOF model which underestimates the value of air concentration [EGHBALZADEH, JAVAN 2012].

Figure 4 shows the simulated water surface profile for different discharges along the stepped spillways with slopes $\theta=45^{\circ}$. It is clear that water flow depth increases by increasing of flow rates. The dimensionless water depth at step edge upstream the inception point obtained by simulation and measurements are depicted in Figure 5. A very satisfactory agreement can be observed between both results. This result is qualitatively similar to those presented by BOMBARDELLI et al. [2011]. The profile of normalized water surface elevation was best fitted by the following equations (see Fig. 5):
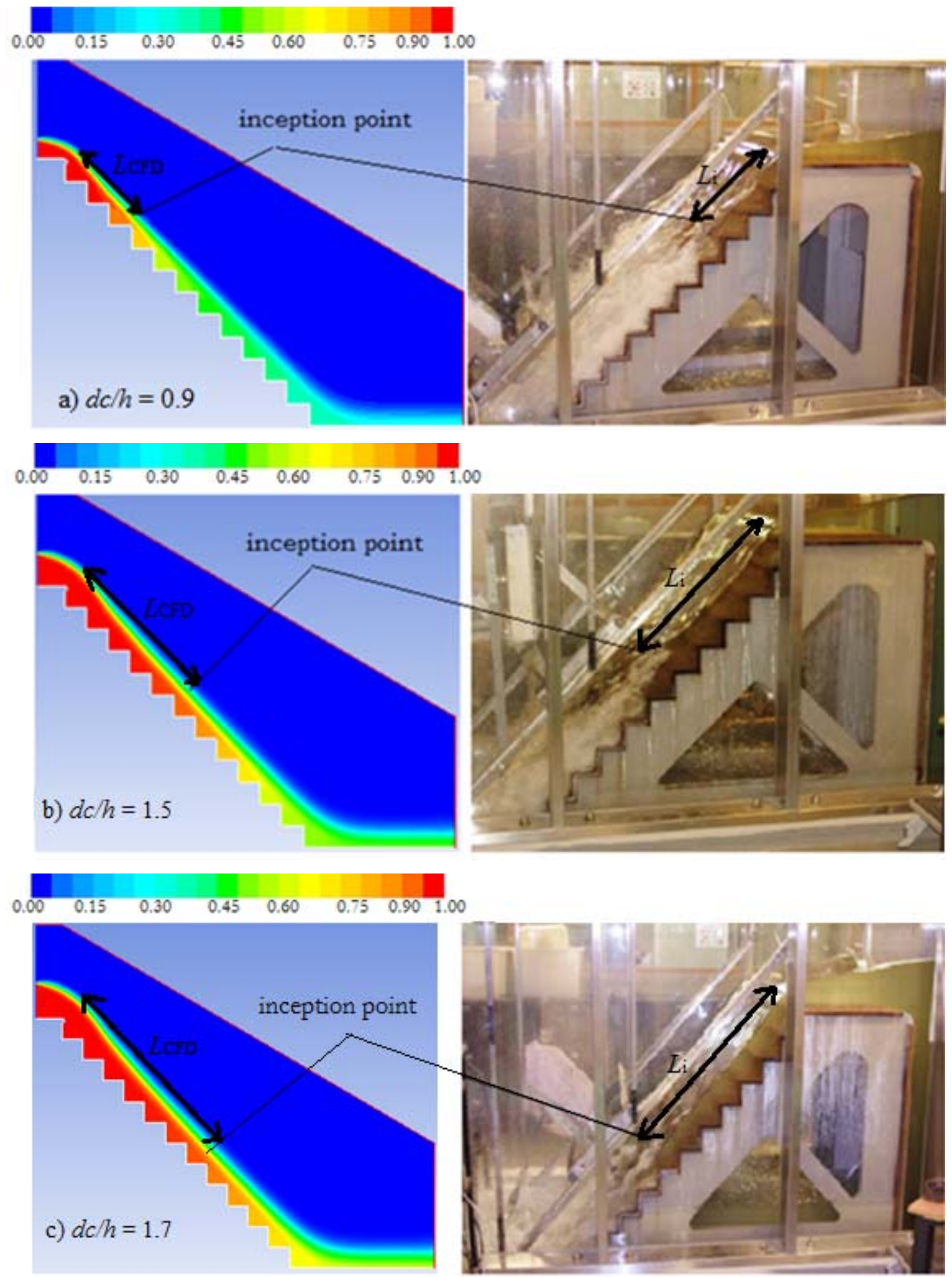

Fig. 3. Measured and computed inception point for different discharges; $d_{c}=$ critical flow depth, $h=$ step height, $L_{C F D}=$ calculated longitudinal distance to the inception point; source: own elaboration 


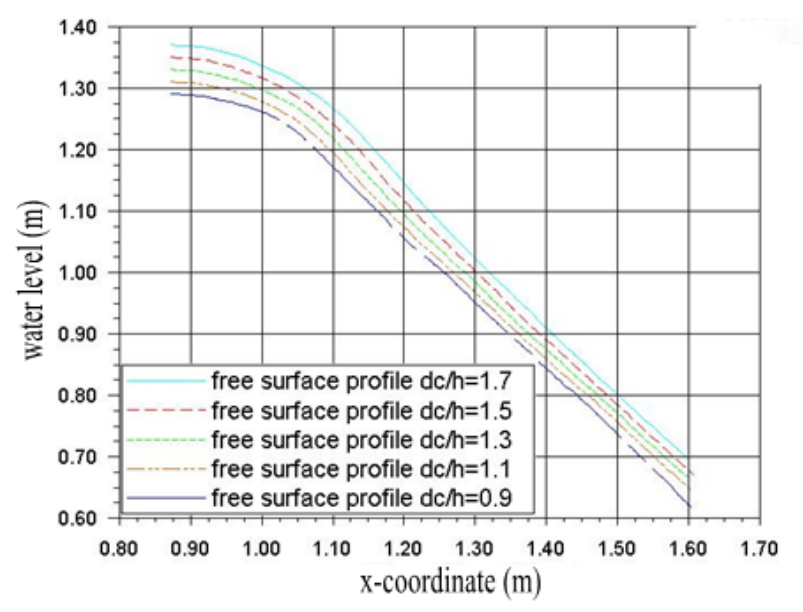

Fig. 4. Free surface obtained by Ansys Fluent; $d_{c}=$ critical flow depth, $h=$ step height; source: own study

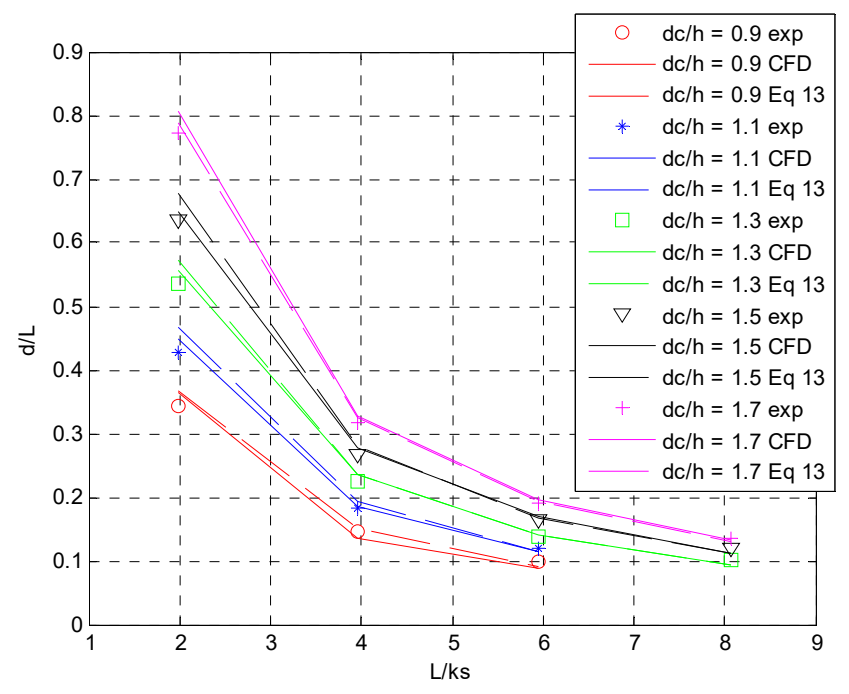

Fig. 5. Comparison between results obtained on the basis of the Equation (13) and normalised water depth obtained by experimental (exp) and by Ansys Fluent (CFD); $d=$ water depth, $L=$ streamwise distance, $k_{s}=$ roughness height, $d_{c}=$ critical flow depth, $h=$ step height; source: own study

$$
\frac{d}{L}=\left(\frac{d_{c}}{h}\right)^{1.2}\left(\frac{L}{k_{S}}\right)^{-1.28}
$$

Where: $d=$ water depth; $L=$ the streamwise distance from the spillway crest; $h=$ step height; $k_{s}=h \cos (\theta)$ and $d_{c}=$ critical flow depth.

The start of air entrainment is defined by the point where the boundary layer thickness reaches the water depth $(\delta \approx d)$, so the distance from the start of growth of boundary layer to the inception point of air $L_{\text {incp }}$ can be obtained by equality Equation (1) and Equation (13):

$$
\begin{aligned}
\frac{\delta}{L_{\text {incp }}} & \approx \frac{d}{L_{\text {incp }}} \\
\Rightarrow 0.15\left(\frac{L_{\text {incp }}}{k s}\right)^{-0.37} & \approx\left(\frac{d_{c}}{h}\right)^{1.2}\left(\frac{L_{\text {incp }}}{k s}\right)^{-1.28}
\end{aligned}
$$

which can be rearranged to give

$$
\frac{L_{\text {incp }}}{k s} \approx 8.0426\left(\frac{d_{c}}{h}\right)^{1.32}
$$

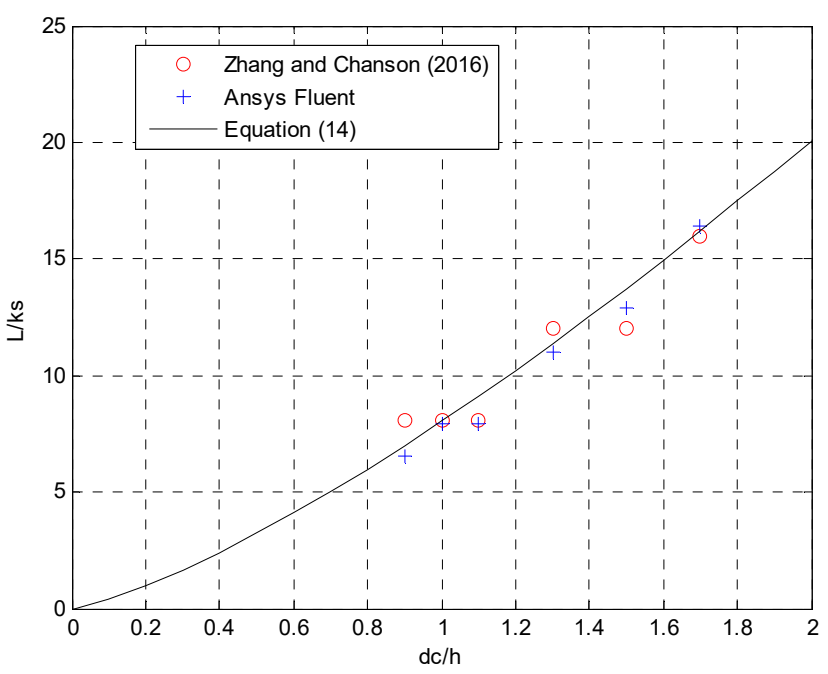

Fig. 6. Comparison between dimensionless locations of inception point and the correlation; $d_{c}, h$ as in Fig. $4, L, k_{s}$ as in Fig. 5; source: own study

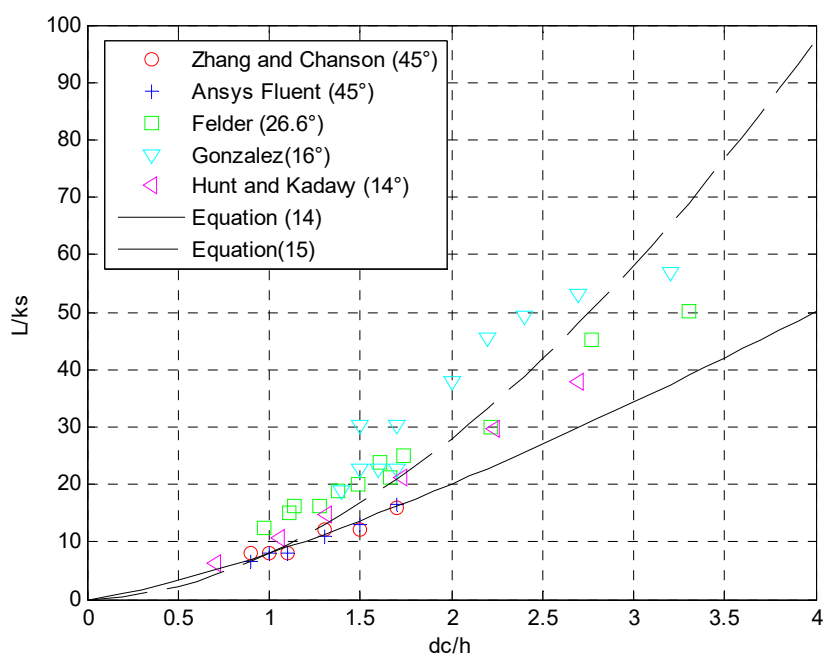

Fig. 7. Comparison between dimensionless locations of inception point and the correlations for different chute slopes; $d_{c}, h$ as in Fig. 4, $L, k_{s}$ as in Fig. 5; source: own study

From Figure 6 , the agreement between $L_{i}, L_{\mathrm{CFD}}$ and Equation (14) is very good and its applicable for chute slope equal to $45^{\circ}$.

Figure 7 showed that this formulae tended to under predict the location of inception point for chute slopes little than $30^{\circ}$ when its compared by experimental data of FELDER [2013], GONZALEZ [2005] and HuNT and KADAVY [2009] (see Tab. 3). To optimize more Equation (14), the exponent 1.32 to $\left(d_{c} / h\right)$ was changed by the power fit exponent of 1.8 and overall data was well fitted by the following relationship (see Fig. 7):

$$
\frac{L_{\text {incp }}}{k s} \approx 8.0426\left(\frac{d_{c}}{h}\right)^{1.8}
$$

In order to explore more characteristics of flow over stepped spillways; the contour of longitudinal velocity in stepped spillway is plotted in Figure 8. The velocity magnitude increase in the streamwise direction as a coherent stream because the entrained air reduces wall friction; also 
Table 3. Characteristics of laboratory studies

\begin{tabular}{|l|c|c|c|c|}
\hline Experimental data & $\begin{array}{c}q \\
\left(\mathrm{~m}^{2} \cdot \mathrm{s}^{-1}\right)\end{array}$ & $\begin{array}{c}\text { Chute } \\
\text { slope }\left({ }^{\circ}\right)\end{array}$ & $\begin{array}{c}\text { Step height } \\
(\mathrm{m})\end{array}$ & $\begin{array}{c}\text { Step length } \\
(\mathrm{m})\end{array}$ \\
\hline FELDER [2013] & $0.005-0.241$ & 26.6 & $0.1-0.05$ & $0.2-0.1$ \\
\hline GONZALEZ [2005] & $0.1468-0.2195$ & 16 & $0.1-0.05$ & $0.35-0.175$ \\
\hline $\begin{array}{l}\text { HUNT and } \\
\text { KADAVY [2009] }\end{array}$ & $0.11-0.82$ & 14 & 0.152 & 0.61 \\
\hline
\end{tabular}

Explanations: $q=$ flow rate.

Source: own study.

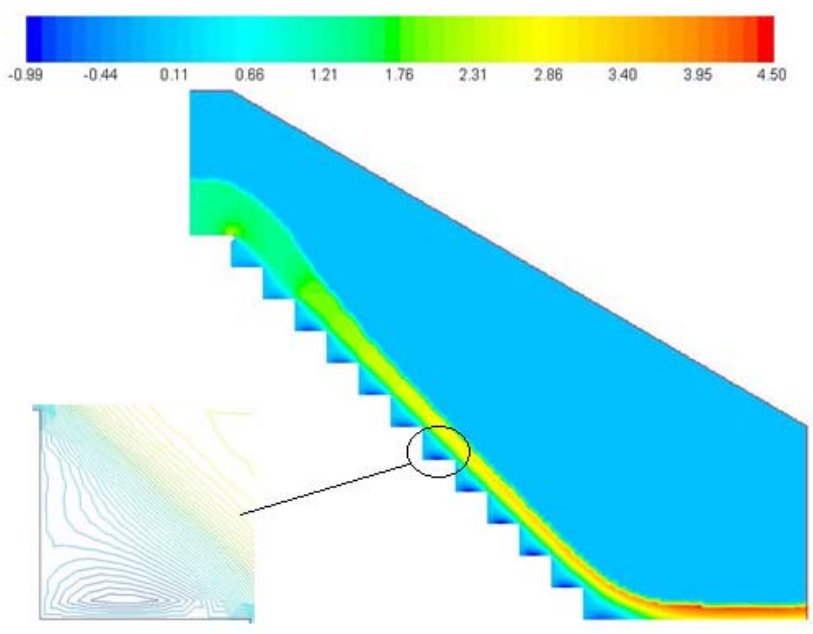

Fig. 8. X-velovity contour along stepped spillway for $q=0.22 \mathrm{~m}^{2} \cdot \mathrm{s}^{-1}$; source: own study

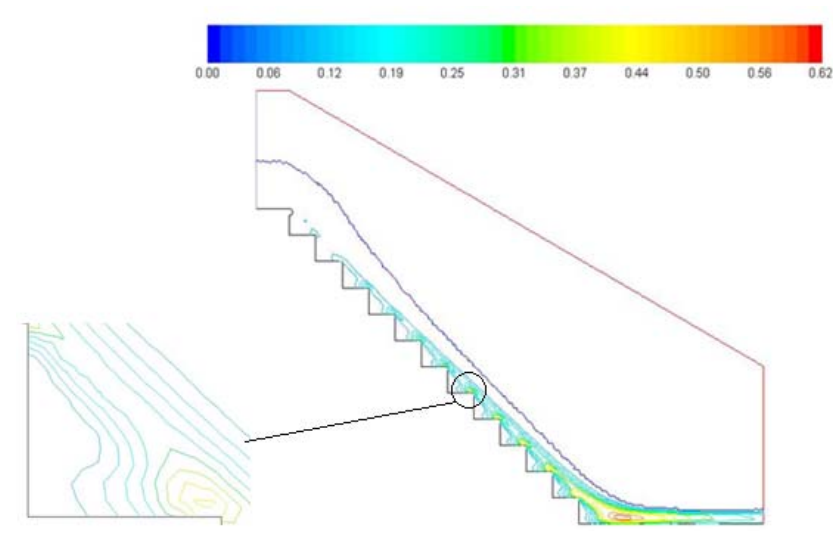

Fig. 9. Turbulence kinetic energy along the stepped spillway for $q=0.22 \mathrm{~m}^{2} \cdot \mathrm{s}^{-1}$; source: own study

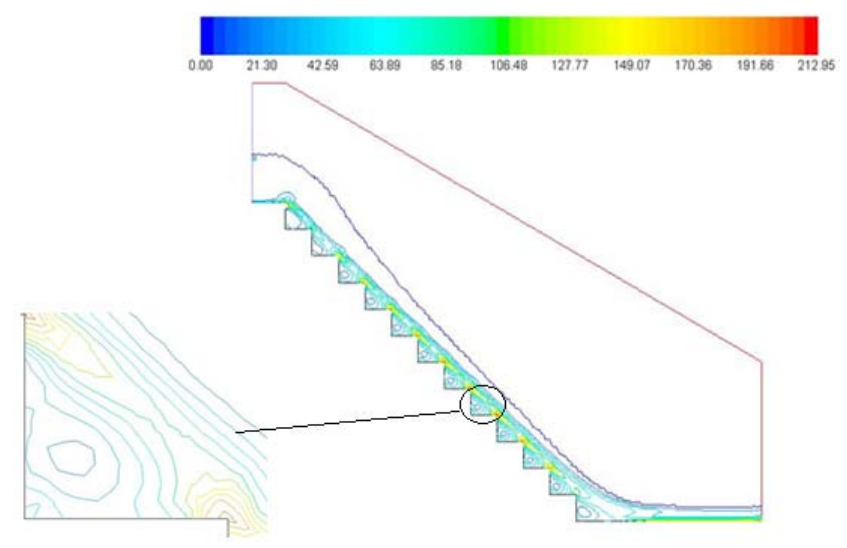

Fig. 10. Shear strain rate along the stepped spillway for $q=0.22 \mathrm{~m}^{2} \cdot \mathrm{s}^{-1}$; source: own study the fluid is accelerated by the gravity along the chute. In the step corner, the recirculation flow is developed. Most of the energy is dissipated by momentum transfer between the skimming flow and the eddy in the interior of the step. Velocity fields present similar shape to those presented by QIAN et al. [2009].

Figure 9 and 10 present the isolines of kinetic turbulent energy $k$ and shear strain contour $S_{i j}$ along stepped spillway for $q=0.22 \mathrm{~m}^{2} \cdot \mathrm{s}^{-1}$. As can be seen from these figures, the maximum of $k$ and $S_{i j}$ are located near the pseudo-bottom as a region of formation and growth of recirculating vortices. Also it can be observed the increasing of turbulent kinetic energy and shear strain along the stepped spillway which is the result of the development of the boundary layer. A gradual decrease of $k$ and $S_{i j}$ is observed near the water surface, where the flow can be considered irrotational. It is obvious that the turbulent kinetic energy proportional to the rate of deformation of fluid elements (see Eq. 6). These results are qualitatively similar to those presented by BOMBARDELLI et al. [2011] for kinetic energy turbulent and FRIZELL et al. [2013] for shear strain rate.

\section{CONCLUSIONS}

In this study, flow over stepped spillway was simulated by using Ansys Fluent. Free surface was treated by VOF model and turbulence flow was estimated by $k-\varepsilon$ Standard Model. In Ansys Fluent, air entrainment start when fraction of water is less than unity and with this method, the inception point is determined. Good agreement is found between numerical and experimental results. The values of computed and measured water depth at the inception point are very close. Although the difference between the numerical and experimental inception point locations are small. It was found that the inception point moves toward the basin floor when the discharge increases. Two relationships are established (Eqs. 13 and 14) for determining the variation of dimensionless water depth upstream of inception point and the location of the inception point for channel slope $\theta=45^{\circ}$. The comparison of computed values with experimental data and thus formulas are well. However, Equation (14) under predict the inception point when chute slopes are moderate or flat and its optimized to more accurately predict the location of the inception point (equation 15). The magnitudes of longitudinal of velocity, kinetic energy turbulent and shear strain grows in flow direction. The findings of this numerical study confirmed that the Ansys Fluent is a robust software for simulating air entrainment and exploring more characteristics of flow over stepped spillways.

\section{REFERENCES}

Ansys Inc. 2014. ANSYS Fluent Version 15.0.7.

Bentalha C., HaBi M. 2015. Numerical simulation of air entrainment for flat-sloped stepped spillway. Journal of Computational Multiphase Flows. Vol. 7. No. 1 p. 33-41.

Boes R.M., HAgER W.H. 2003. Two-phase flow characteristics of stepped spillways. Journal of Hydraulic Engineering. Vol. 129. No. 9 p. $661-670$. 
Bombardelli F.A., Meireles I., Matos J. 2011. Laboratory measurements and multi-block numerical simulations of the mean flow and turbulence in the non-aerated skimming flow region of steep stepped spillways. Environmental Fluid Mechanics. Vol. 11. Iss. 3 p. 263-288. DOI $10.1007 / \mathrm{s} 10652-$ 010-9188-6.

Chanson H. 1997. Air bubble entrainment in free-surface turbulent shear flows. London. Academic Press. ISBN 0-12168110-6 pp. 401.

Chanson H. 2001a. The hydraulics of stepped chutes and spillways. Rotterdam. Balkema Publ. ISBN 9789058093523 pp. 424.

Chanson H. 2001b. Hydraulic design of stepped spillways and downstream energy dissipators. Dam Engineering. Vol. 11. No. 4 p. 205-242.

CHEN Q., DAI G.Q., LIU H.W. 2002. Volume of fluid model for turbulence numerical simulation of stepped spillway over flow. Journal of Hydraulic Engineering. Vol. 128. No. 7 p. $683-688$.

Cheng X., Chen Y., Luo L. 2006. Numerical simulation of airwater two-phase flow over stepped spillways. Science in China. Ser. E. Technological Sciences. Vol. 49. No. 6 p. 674684.

Christodoulou G.C. 1993. Energy dissipation on stepped spillways. Journal of Hydraulic Engineering. Vol. 119. No. 5 p. 644-650.

EghBalzadeH A., Javan M. 2012. Comparison of mixture and VOF models for numerical simulation of air-entrainment in skimming flow over stepped spillway. Procedia Engineering. Vol. 28 p. 657-660.

FELDER S. 2013. Air-water flow properties on stepped spillways for embankment dams: aeration, energy dissipation and turbulence on uniform, non-uniform and pooled stepped chutes. $\mathrm{PhD}$ Thesis. Brisbane. School of Civil Engineering, The University of Queensland, Australia pp. 454.

Frizell K.W., RenNa F.M., Matos J. 2013. Cavitation Potential of Flow on Stepped Spillways. Journal of Hydraulic Engineering. ASCE. Vol. 139. No. 6 p. 630-636.
GONZALEZ C.A. 2005. An experimental study of free-surface aeration on embankment stepped chutes. PhD Thesis. Brisbane. Department of Civil Engineering, The University of Queensland, Australia pp. 240.

HUNT S.L., KADAVY K.C. 2009. Inception point relationships for flat-slopped stepped spillways. ASABE Paper. No. 096571 St. Joseph, Mich. ASABE.

LAUNDER B.E., SPALDING D.B. 1974. The numerical computation of turbulent flows, computer methods in applied. Mechanics and Engineering. Vol. 3 p. 269-289.

Qian Z., Hu X., HUAi W., AMAdOR A. 2009. Numerical simulation and analysis of water flow over stepped spillways. Science in China. Ser. E. Technological Sciences. Vol. 52. No. 7 p. 1958-1965.

RAJARATNAM N. 1990. Skimming flow in stepped spillways. Journal of Hydraulic Engineering.Vol. 116. No. 4 p. 587591.

Rice CH.E., KADAvy K.C. 1996. Model of a roller compacted concrete stepped spillway. Journal of Hydraulic Engineering. Vol. 122. No. 6 p. 292-297.

Sarfaraz M., AtTARi J., Pfister M. 2012. Numerical Computation of Inception Point Location for Steeply Sloping Stepped Spillways [9th International Congress on Civil Engineering]. [8-10.05.2012 Isfahan].

WoOd I.R., ACKers P., LOVELESS J. 1983. General method for critical point on spillways. Journal of Hydraulic Engineering. Vol. 109. No. 2 p. 308-312.

ZHANG G., ChANSON H. 2015. Hydraulics of the developing flow region of stepped cascades: an experimental investigation. Report CH97/15. Brisbane. School of Civil Engineering, The University of Queensland pp. 78.

ZHANG G., CHANSON H. 2016. Hydraulics of the developing flow region of stepped spillways. I: Physical modeling and boundary layer development. Journal of Hydraulic Engineering. Vol. 142. No. 7: 04016015.

\section{Chakib BENTALHA, Mohammed HABI}

\section{Profil swobodnej powierzchni w warunkach przepływu przez przelew schodkowy i położenie turbulentnej przydennej warstwy granicznej: Studia numeryczne}

\section{STRESZCZENIE}

Przelew schodkowy jest budowlą hydrauliczną projektowaną w celu rozpraszania nadmiaru energii kinetycznej i przez to ograniczenia koniecznej głębokości w stanowisku dolnym. Przepływ przez przelew schodkowy charakteryzuje się dużym napowietrzeniem strumienia, co może zapobiec lub zmniejszyć uszkodzenia kawitacyjne powierzchni zlewowej przelewu. Porywanie powietrza rozpoczyna się tam, gdzie turbulentna przydenna warstwa graniczna osiąga swobodną powierzchnię przepływu; ten punkt nazywano ,punktem początkowym”. Położenie punktu początkowego w pracy określano na podstawie wyników obliczeń programem Ansys Fluent, wykorzystującym metodę objętości skończonych płynu (VOF) wraz ze standardowym zamknięciem modelu turbulencji $k-\varepsilon$ stosowanym w obliczaniu przepływu o swobodnej powierzchni. Celem prowadzonych badań było znalezienie nowych zależności do opisania zmian głębokości wody na stopniu schodka i położenia punktu początkowego. Przedstawiono obliczone rozkłady prędkości, turbulentnej energii kinetycznej i naprężeń. Uzyskane wyniki obliczeń są zgodne z wynikami badań eksperymentalnych.

Słowa kluczowe: Ansys Fluent, kaskadowy spust, model VOF, powierzchnia swobodna, punkt początkowy, standardowy model $k-\varepsilon$ 